\title{
Detecting Clouds Associated with Jet Engine Ice Crystal Icing
}

\author{
Julie Haggerty, Eric Defer, Adrianus De Laat, Kristopher Bedka, Jean-Marc Moisselin, \\ Rodney Potts, Julien Delanoë, Frédéric Parol,Alice Grandin, and Stephanie Divito
}

ngestion of large amounts of ice crystals by jet engines, known as the ice crystal icing (ICI) hazard, appears to be the culprit in more than 150 jet engine power-loss and damage events during the past two decades (Fig. 1). Typically occurring near tropical convective systems, ICI events may also impact heated inlets used by an aircraft's air data system. Although the heat within an engine or inlet would presumably prevent any ice buildup, analyses of engine power-loss events attributed to ICI together with wind tunnel testing suggest that significant amounts of ice can accrete inside sensitive parts of an aircraft engine. Ice accretion and subsequent ice shedding into engine cores during flight can adversely affect engine performance and damage engine components. Early research by Lawson et al. (1998) and Mason et al. (2006) suggested that engine power-loss events were attributable to ingestion of high concentrations of small ice crystals.
Fig. I. Locations of confirmed ICl events on Boeing aircraft as of 2015. Adapted from Bravin et al. (2015).

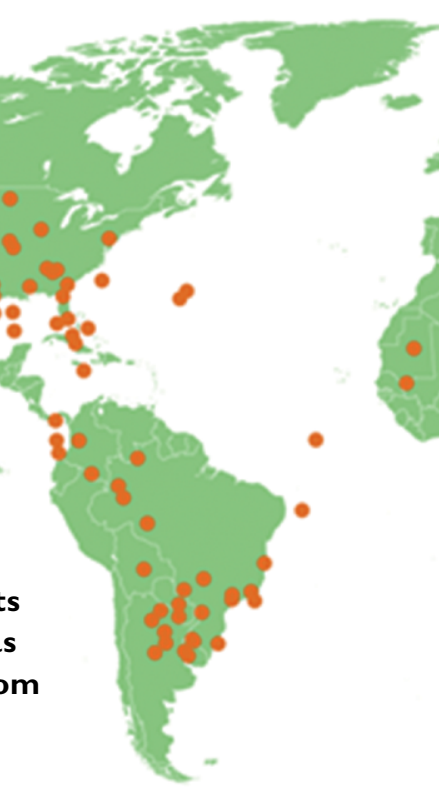

AFFILIATIONS: HAGGERTY-National Center for Atmospheric Research, Boulder, Colorado; DefER - Laboratoire d'Aérologie, Université de Toulouse, CNRS, OMP, UPS, Toulouse, France; De LAAT—KNMI, de Bilt, Netherlands; BedKA-NASA Langley Research Center, Hampton, Virginia; MoIsSELIN-MétéoFrance, Toulouse, France; PotTs-Bureau of Meteorology, Melbourne, Victoria, Australia; DeLANOË-LATMOS, IPSL, UVSQ, Guyancourt, France; PAROL-Laboratoire d'Optique Atmosphérique, Université des Sciences et Technologies de Lille, CNRS, Lille, France; GraNDIN-Airbus, SAS, Toulouse, France;
DIVITO-William J. Hughes Technical Center, Federal Aviation Administration, Atlantic City, New Jersey CORRESPONDING AUTHOR: Julie Haggerty, haggerty@ucar.edu DOI:10.II75/BAMS-D-17-0252.I

(C)2019 American Meteorological Society For information regarding reuse of this content and general copyright information, consult the AMS Copyright Policy. 
The occurrence of engine power loss under atmospheric conditions not formerly recognized as hazardous initiated investigation of the clouds, convection, and microphysics associated with ICI events. Analyses of the meteorological conditions associated with these events revealed several common attributes. ICI hazards tend to occur near cores of deep convection and associated cirrus anvils. Flight-level X-band radar reflectivity is generally below 20-30 dBZ (Grzych and Mason 2010), suggesting that small ice crystals constitute the bulk of the ice mass encountered. Areas of heavy precipitation below flight level are sometimes observed. Any reports of turbulence are generally light to moderate, and there is no significant airframe ice accretion, precluding the existence of supercooled liquid water. ICI events occur over a temperature range of $-58^{\circ}$ to $-3^{\circ} \mathrm{C}$ and at altitudes from 11,000 to $45,000 \mathrm{ft}$ according to Bravin et al. (2015).

Following analysis of ICI events, an international consortium of researchers assembled to investigate the scientific and engineering aspects of ice crystal icing. The U.S.-led High Ice Water Content (HIWC) and the European High Altitude Ice Crystal (HAIC) projects brought researchers together with aviation engineers, operators, and regulators from Europe, North America, and Australia. Their objectives are to develop a better understanding of the relevant meteorology, explore critical engineering questions, develop new aircraft certification standards, and formulate mitigation strategies for the aviation industry. Sponsored by the U.S. Federal Aviation Administration (FAA), the European Union Seventh Framework Programme for Research and Technological Development (FP7), National Aeronautics and Space Administration (NASA), the European Aviation Safety Agency (EASA), the Australian Bureau of Meteorology (BoM), Transport
Canada, Airbus, and Boeing, multiple research teams are investigating the meteorological processes associated with high ice water content (IWC).

A central objective of these efforts is to understand the dynamic, thermodynamic, and microphysical cloud processes that result in potentially hazardous concentrations of ice crystals in some convective clouds. A review of current research in these areas is beyond the scope of this paper but can be found elsewhere (e.g., Leroy et al. 2017; Ackerman et al. 2015; Stanford et al. 2017).

\section{DETECTION OF HIGH-IWC CONDITIONS.}

An area of active research within the international consortium is the development of high-IWC satellite detection and nowcasting techniques based on available remote sensing technology and numerical weather prediction (NWP) models. These techniques attempt to identify areas of high IWC and could enable the provision of alerts to the aviation industry. Such information is needed because, while new engine certification standards may largely mitigate the risks associated with ICI for future aircraft engines, there is a large, currently susceptible fleet that will be operating for many years. Thus, there is a recognized need for nowcasting guidance products to support flight planning and management of the strategic and tactical response for these aircraft.

Various research teams are investigating methods for detecting the high-IWC conditions associated with ICI. Multiple techniques have been developed using geostationary (GEO) and polar-orbiting satellite products, NWP model fields, and ground-based radar data as the basis for high-IWC warning products (Table 1). Described below are the approaches of teams within the original HIWC-HAIC research partnership.

TABLE I. HIWC diagnostic products.

\begin{tabular}{|c|c|c|}
\hline Product name (developer) & Input data type(s) & Output field \\
\hline MSG CPP HIWC mask (KNMI) & CPP satellite products & Yes/no HIWC \\
\hline DARDAR (LATMOS) & CloudSat, CALIPSO & IWC vertical profiles \\
\hline PHIWC (NASA) & $\begin{array}{l}\text { Overshooting cloud-top/anvil texture } \\
\text { detection, LaRC SatCORPS, } \\
\text { GEO cloud property retrieval }\end{array}$ & HIWC potential \\
\hline ALPHA (NCAR) & $\begin{array}{l}\text { NWP model, ground-based radar, } \\
\text { GEO satellite products }\end{array}$ & HIWC potential \\
\hline RDT (Météo-France) & $\begin{array}{l}\text { GEO satellite data (main input data), } \\
\text { NWP, lightning }\end{array}$ & Areas of rapidly developing convection \\
\hline
\end{tabular}



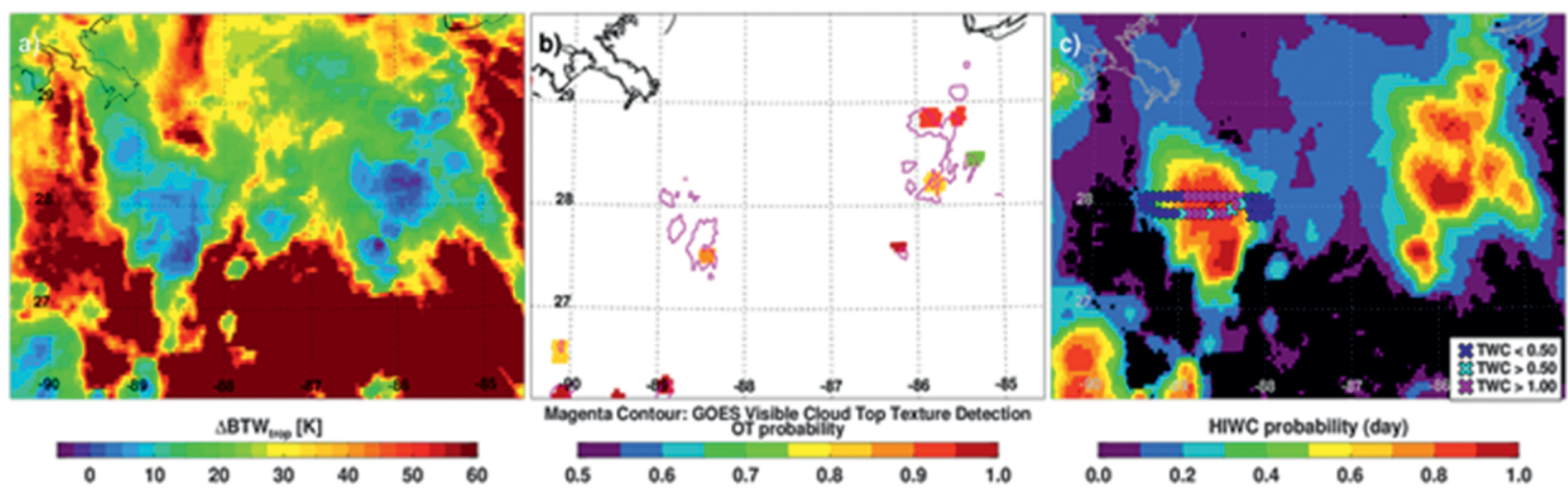

FIG. 2. (a) Tropopause-relative GOES-I4 IR brightness temperature (GOES minus tropopause). Cool colors indicate cloud tops near to or above the tropopause. (b) GOES IR overshooting top detection probability (color shading; values $>0.7$ shown) and visible texture detection (magenta contours). (c) NASA LaRC PHIWC overlaid with a 10-min segment of TWC collected by the NASA DC-8 aircraft during the 2015 Fort Lauderdale flight campaign. Aircraft positions are colored by the observed TWC, showing a sharp transition when the aircraft entered a region of high PHIWC $(>0.6)$ driven by cloud tops near the tropopause and close proximity to overshooting cloud tops.

Meteosat Second Generation Cloud Physical Properties high-IWC mask. The Royal Netherlands Meteorological Institute (KNMI) developed a geostationary satellite data product for identifying atmospheric conditions thought to favor ICI. Using daytime retrievals of cloud-top height, cloud-top temperature, and condensed water path from the Cloud Physical Properties (CPP) algorithm, the method sets thresholds on each variable to assemble a mask indicating areas of high IWC. The mask was successfully implemented on near-real-time imagery from various geostationary satellites. It has been evaluated against measurements from several field campaigns, used for real-time field campaign planning purposes, and applied to construct climatologies of the occurrence of ICI conditions. The Meteosat Second Generation (MSG) CPP high-IWC mask is currently available via the KNMI MSG CPP web portal (http://msgcpp.knmi.nl). The algorithm was also adapted to low-orbit Moderate Resolution Imaging Spectroradiometer (MODIS) observations and has been integrated in the Rapidly Developing Thunderstorms (RDT) data product (see below).

DARDAR products. The radar-lidar (DARDAR) product provides cloud properties by combining, through a synergistic variational algorithm, coincident spaceborne measurements of both the CloudSat $(95 \mathrm{GHz})$ radar and Cloud-Aerosol Lidar and Infrared Pathfinder Satellite Observations (CALIPSO) (532 and 1,064 nm) lidar, both instruments being part of the low-orbit A-Train mission. The DARDAR algorithm retrieves vertical profiles of IWC, effective radius, particle size distribution, cloud phase, and cloud classification. It utilizes lidar sensitivity to highly concentrated small ice crystals along with the capability of the radar to penetrate optically thick ice clouds. The DARDAR product was used to statistically and geographically document at the global scale the occurrence of high IWC, whatever its vertical altitude, and also to tune and validate other high-IWC products. A similar algorithm, based on radar alone, was applied to the Radar System Airborne (RASTA) cloud radar observations collected during various field campaigns, providing closure between airborne in situ measurements and remote sensing retrievals.

NASA LaRC PHIWC. Airborne in situ IWC observations collected during three field campaigns (described below) were used to identify Geostationary Operational Environmental Satellite (GOES) and Multifunctional Transport Satellite-1 Replacement (MTSAT-1R) satellite-derived parameters coincident with high IWC. Analysis of these flights show 1) an exponential IWC increase during flight within $40 \mathrm{~km}$ of a convective updraft region; 2) an exponential IWC increase during flight within or beneath increasingly cold cloud tops, normalized by the regional NWP model tropopause temperature (Fig. 2a); and 3) a linear IWC increase with increasing cloud optical depth (daytime only) derived using the Langley Research Center (LaRC) Satellite Cloud and Radiative Property Retrieval System (SatCORPS). These relationships 


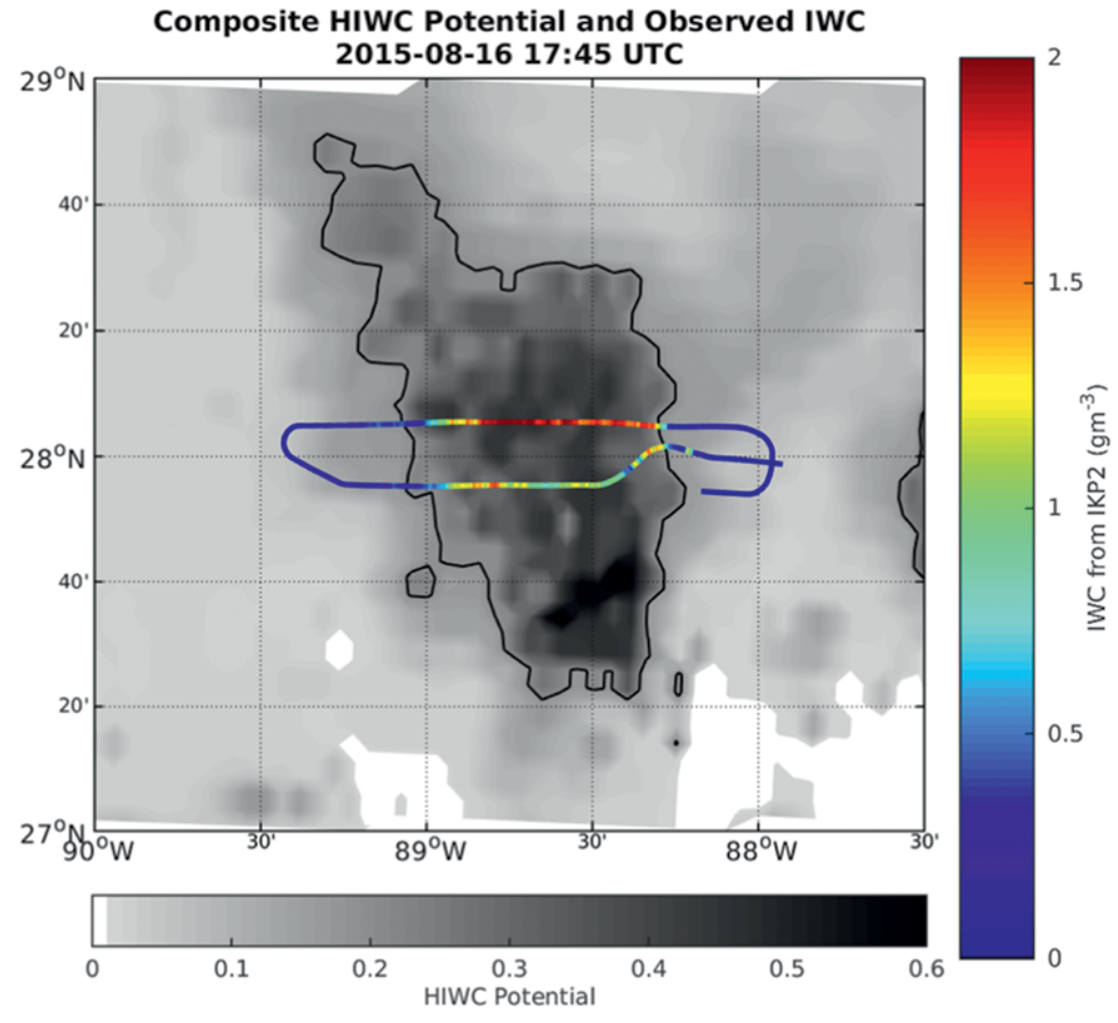

FIG. 3. NCAR's ALPHA HIWC potential product (gray scale indicates maximum value in vertical column) in the Gulf of Mexico on I745 UTC I6 Aug 2015. The black contour encloses an area with HIWC potential $>0.2$. Color scale indicates IWC along a 30-min flight segment of the NASA DC-8. swarm optimization is used to select specific input variables, define membership functions, and determine weighting factors for optimal blending of the various data (Fang et al. 2008). Output from ALPHA is a three-dimensional gridded field of HIWC potential (which can be thought of as an uncalibrated probability). The HIWC potential field consists of output based on satellite, NWP model, and radar data (3-input algorithm) and on satellite and NWP model data only where radar data are not available (2-input algorithm). An example of HIWC potential, which blends output from the 2 - and 3 -input versions of the algorithm, is shown in Fig. 3 with in situ IWC measurements superimposed. were used to derive fuzzy logic membership functions that serve as the foundation for the NASA LaRC Probability of High IWC (PHIWC) product (Fig. 2c). Automated pattern recognition of overshooting cloud tops and anvil texture are used to define convective updraft regions (Fig. 2b). The PHIWC product is designed to operate during both day and night and can be generated using any global polar-orbiting or geostationary visible/IR imager.

ALPHA. Algorithm for the Prediction of HIWC Areas (ALPHA), developed at the National Center for Atmospheric Research (NCAR), is a three-dimensional diagnostic tool that uses operationally available satellite data, NWP model data, and ground-based radar data (where available) as input. The three-dimensional NWP model and radar data are blended with the two-dimensional satellite data via a set of fuzzy logic membership functions that exploit the strengths of each dataset. A machine learning technique is applied to tune the algorithm using research aircraft measurements in high-IWC conditions. Particle
RDT. RDT software is developed by Météo-France in the framework of European Organisation for the Exploitation of Meteorological Satellites (EUMETSAT)'s Satellite Application Facility for Nowcasting (NWCSAF). RDT uses brightness temperatures from geostationary satellites with the option of using NWP products or lightning data. RDT detects, tracks, and extrapolates thunderstorm cells. RDT also characterizes observed systems with different attributes such as cooling rate, top of thunderstorm, and horizontal extension. High-IWC values are often associated with deep convection and especially strong updrafts that inject significant quantities of water into the upper troposphere.

FIELD EXPERIMENTS. A series of field experiments in tropical regions with high incidence of ICI events provided research aircraft data for development and validation of nowcasting methods (Strapp et al. 2016; Dezitter et al. 2013). The HIWC and HAIC projects jointly conducted experiments in Darwin, Northern Territory, Australia [23 flights by 
the Service des Avions Français Instrumentés pour la Recherche en Environnement (SAFIRE) Falcon 20 in January-March 2014; Fig. 4], and Cayenne, French Guiana (17 flights by the SAFIRE Falcon 20 and 10 flights by the Canadian Convair 580 during May
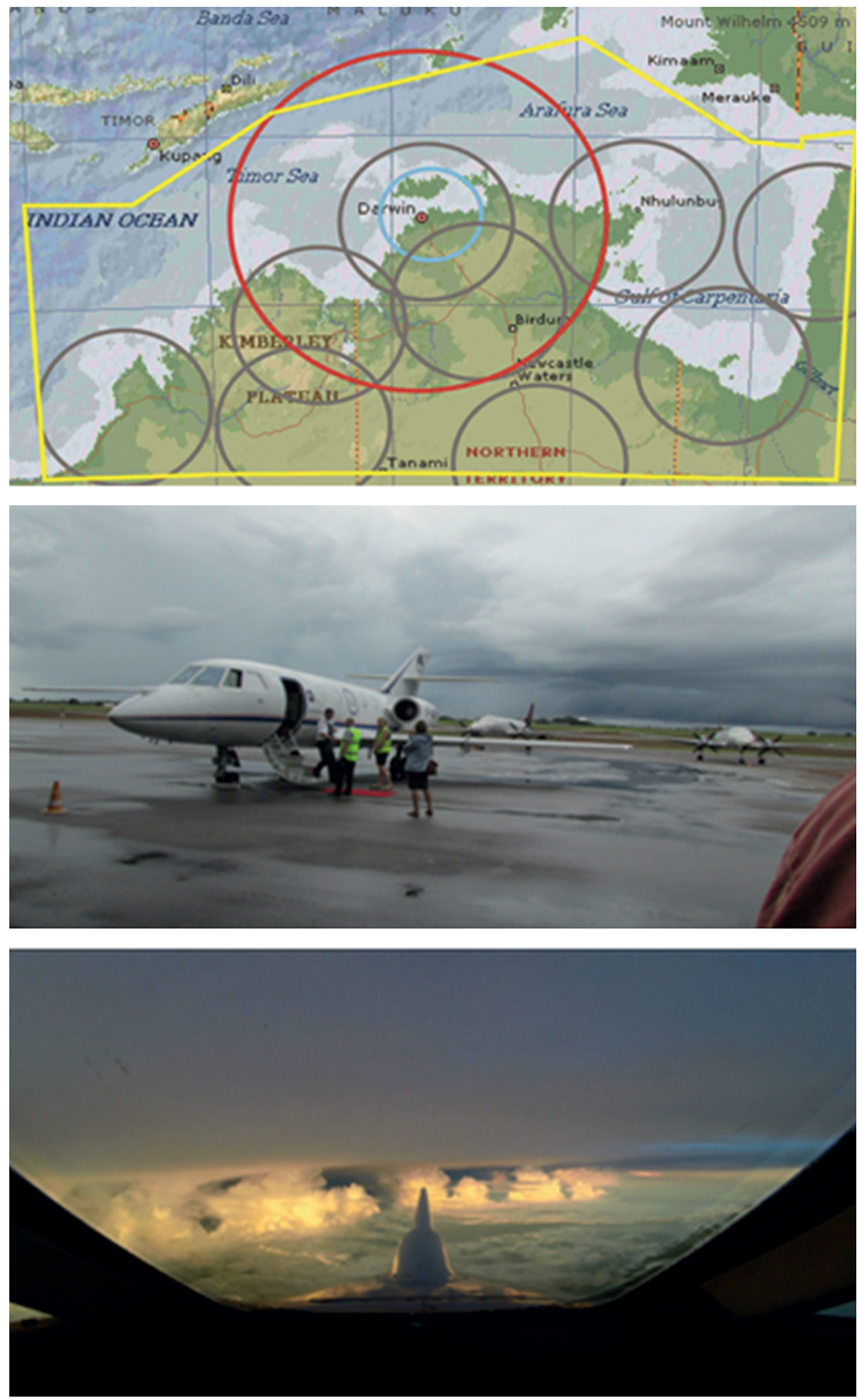

FIG. 4. (top) Operating area of the HAIC-HIWC Darwin flight campaign (yellow polygon) with ground-based radar coverage indicated by gray rings, including the research $\mathrm{C}$-band polarimetric (CPOL) radar (blue ring). The red ring shows a 300-nmi-distance reference. (middle) The SAFIRE Falcon 20 aircraft prepares for a research flight. (bottom) Monsoon convection sampled within the Darwin operating area. Photos provided by T. Ratvasky.
2015). A NASA-led HIWC team executed the HIWC radar study in Fort Lauderdale, Florida [10 flights by the NASA Delta Clipper 8 (DC-8) in August 2015]. The HAIC project conducted a subsequent experiment with the Airbus A340 Manufacturer's Serial Number 1 (MSN 1) flight test aircraft in Darwin and Réunion Island in January 2016.

The payload for all experiments included cloud microphysics probes, total water content (TWC) sensors, enhanced pilot weather radar, and cloud radar. Of particular interest for nowcast product development are measurements of TWC from a newly developed isokinetic evaporator known as the isokinetic probe 2 (IKP2; Davison et al. 2016) and an existing hot-wire probe (Robust probe), as well as vertical IWC profiles from the airborne RASTA cloud radar.

\section{COLLABORATIVE RESEARCH.}

Beginning in 2015, the HAIC and HIWC nowcasting research teams have assembled at a series of dedicated workshops to foster international collaboration on development of high-IWC diagnosis and forecasting methods. Meeting objectives have focused on sharing progress toward development of global high-IWC products and standardizing techniques for evaluating performance of the products. Table 2 lists meeting dates and locations. Meeting agendas featured presentations by each group describing methods used for high-IWC detection, subsequent discussions of the various approaches, and sharing of analyses by each group of designated case studies from the field experiments.

\section{PRODUCT PERFORMANCE.}

One outcome of these workshops is recognition that validation of high-IWC products is complex. The work done by the various HIWC-HAIC teams demonstrates 
that assessing performance of these products and comparing them in a meaningful way is not straightforward. The challenges arise from differences in product attributes as well as validation approaches. Performance statistics are affected by various issues such as

1) sensitivity of results to assumptions used: for example, the IWC threshold used to define cloudy pixels and high IWC;

2) use of differing criteria to collocate in situ data with satellite/model/radar data and to account for spatiotemporal differences in the datasets; and

3) differing objectives of products: for example, RDT identifies convective systems, the MSG CPP highIWC mask provides a binary (yes/no) indicator based on the maximum IWC in a vertical column, and PHIWC and ALPHA estimate the potential for high IWC.
TABLE 2. HIWC Satellite and nowcasting workshops hosted by the HAIC-HIWC partners.

\begin{tabular}{|l|c|}
\hline Location & Date \\
\hline $\begin{array}{l}\text { Toulouse, France } \\
\text { Australia }\end{array}$ & Oct 2015 \\
Toronto, Ontario, & Nov 2015 \\
Canada & May 2016 \\
Toulouse, France & Sept 2016 \\
Capua, Italy & Dec 2016 \\
Toulouse, France & Nov 2017 \\
\hline
\end{tabular}

The HIWC-HAIC teams have worked toward consistent evaluation methods where possible (e.g., issues 1 and 2 noted above), but inherent differences in the various approaches continue to complicate

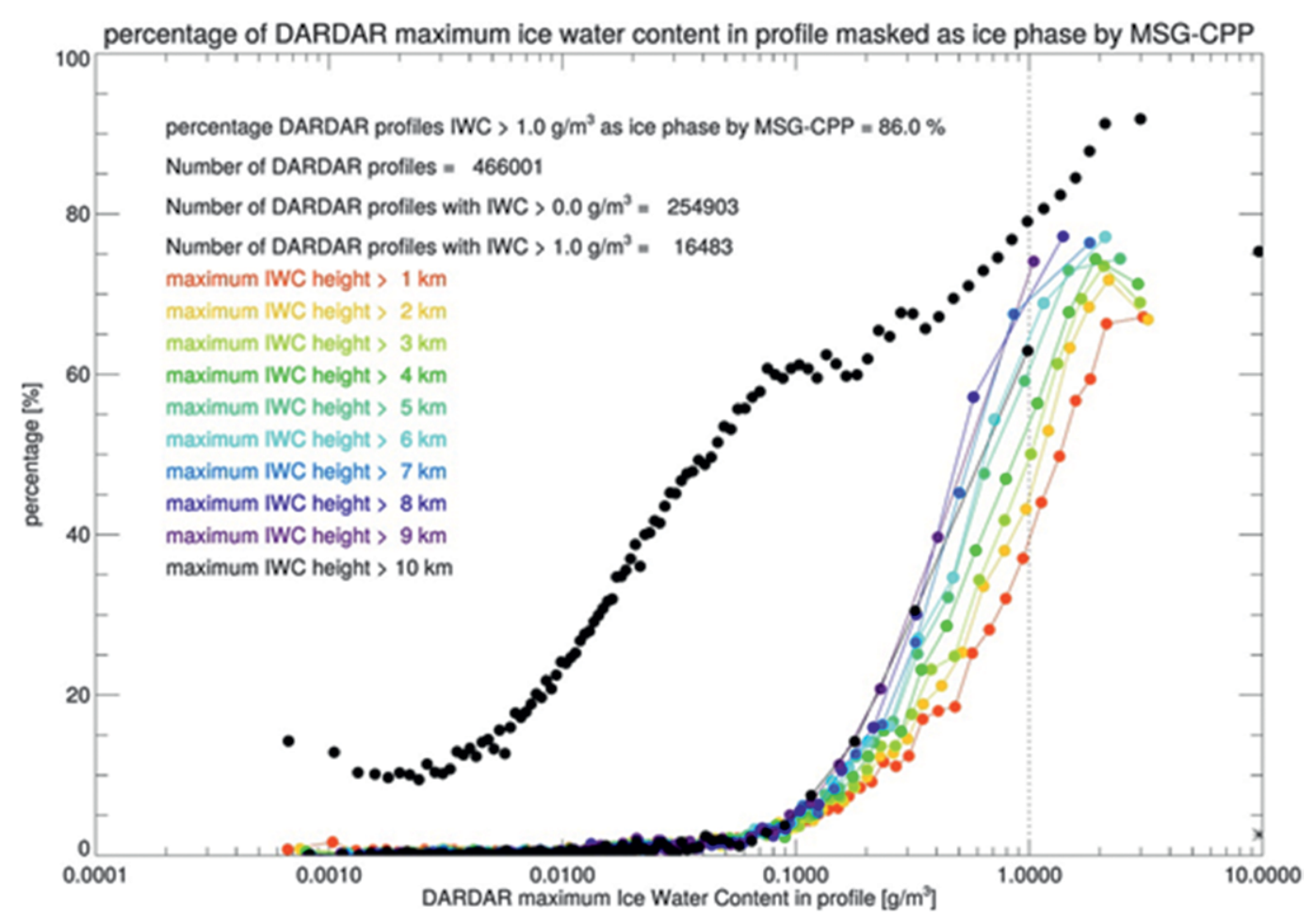

FIG. 5. Percentage (POD) of MSG CPP pixels identified by the high-IWC mask as a function of the maximum IWC values in DARDAR IWC profiles. DARDAR combines data from two Earth observation satellites [CALIPSO lidar and CloudSat radar; see de Laat et al. (2017) for details] and provides high-vertical-resolution cloud and aerosol profiles, including cloud ice/water content. The colored lines indicate the percentage of MSG CPP pixels that qualify for the high-IWC-mask pixels for DARDAR profiles with the height of the maximum IWC above the given altitude. The black dots indicate the number of MSG CPP cloudy pixels identified as ice as a function of the maximum IWC values in DARDAR IWC profiles. Figure adapted from de Laat et al. (2017). 
16 Aug, 2015

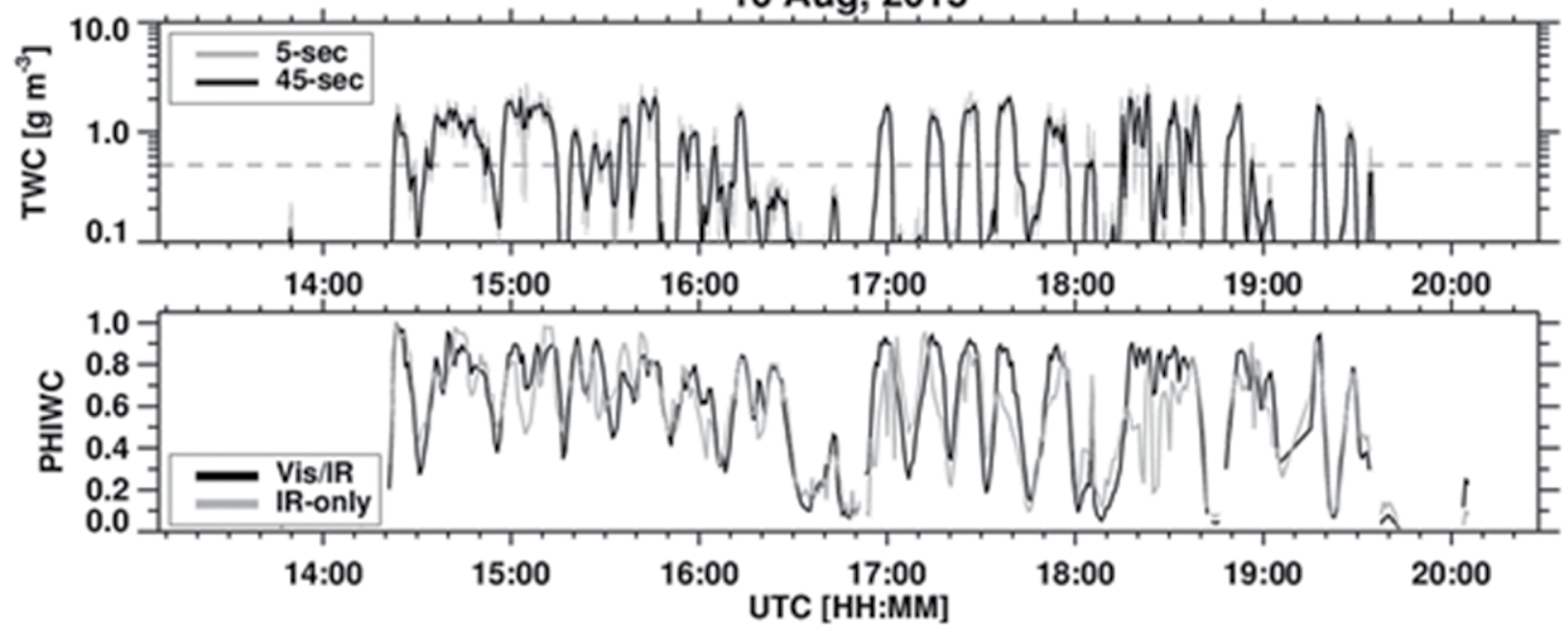

FIG. 6. (top) In situ TWC observations from the IKP2 sensor collected on 16 Aug 2015 aboard the NASA DC-8 aircraft during the Fort Lauderdale flight campaign. IKP2 TWC is averaged to 5- (gray) and 45-s (black) intervals. The 45-s time window, when coupled with the DC-8 airspeed, better represents the area of a GOES satellite infrared channel pixel. (bottom) The LaRC PHIWC product based on inputs with (black) and without (gray) datasets derived using GOES visible channel information.

comparison of product performance. Nevertheless, it is still important for the community to gain a basic understanding of the accuracy of existing products, so each team has compiled relevant statistics to evaluate its approach.

The MSG CPP high-IWC mask product gives a typical probability of detection (POD) around $60 \%-80 \%$ of clouds in which DARDAR IWC exceeds $1 \mathrm{~g} \mathrm{~m}^{-3}$, with a similar false alarm ratio when compared with DARDAR IWC measurements (Fig. 5). The MSG CPP high-IWC mask also rejects the large majority of DARDAR IWC profiles where the maximum IWC does not exceed this IWC threshold value. The LaRC PHIWC and ALPHA HIWC potential products attempt to pinpoint where within deep convection high-IWC conditions are likely, a differing goal relative to the MSG CPP product, which masks areas where high IWC is possible throughout the cloud vertical depth. Both PHIWC and ALPHA have been trained and verified against airborne TWC measurements from the IKP2 during 49 flights in three field campaigns. The two-dimensional PHIWC product, trained on cloudy pixels from the dataset, gives a POD ranging from $60 \%$ to $80 \%$ and a false alarm rate of $20 \%-35 \%$, with best performance offered during daylight hours when cloud optical depth and visible texture retrievals are available and for extremely high-IWC values (e.g., $>2.0 \mathrm{~g} \mathrm{~m}^{-3}$ ). A PHIWC time series derived from GOES-14 1-min super rapid scan observations (Fig. 6) shows that high-IWC conditions (in situ total water content $>0.5 \mathrm{~g} \mathrm{~m}^{-3}$ ) can be resolved quite well. The three-dimensional ALPHA HIWC potential product, trained on both cloudy and clear pixels observed during the flights, shows similar statistics when verified against a reserved set of independent flight-level data from the three field campaigns (i.e., data not used for training of the algorithm). For example, with an assumed HIWC potential threshold of 0.25 and an IWC threshold of $0.5 \mathrm{~g} \mathrm{~m}^{-3}$, ALPHA POD is $76 \%$ and false alarm rate is $25 \%$ in primarily daytime conditions. Figure 7 shows the relationship between measured IWC and HIWC potential as estimated by ALPHA. RDT has been mainly compared with IWC measurements from the Robust probe during the Cayenne field campaign. When RDT cells are matched with IWC measurements, it appears that (for 11 out of 16 flights) 70\% of values of IWC above $1.0 \mathrm{~g} \mathrm{~m}^{-3}$ fall within an RDT cell. For four flights, over $90 \%$ of high-IWC values fall within an RDT cell.

While the IWC threshold used to define high IWC is still under discussion by the research community and aviation regulators, values of 0.5 and $1.0 \mathrm{~g} \mathrm{~m}^{-3}$ have been used to compile performance statistics. Currently, the in situ IWC threshold is the accepted metric within the ICI community. However, the community accepts this in part only because of the lack of comprehensive information about ICI events. In situ IWC exceeding the 


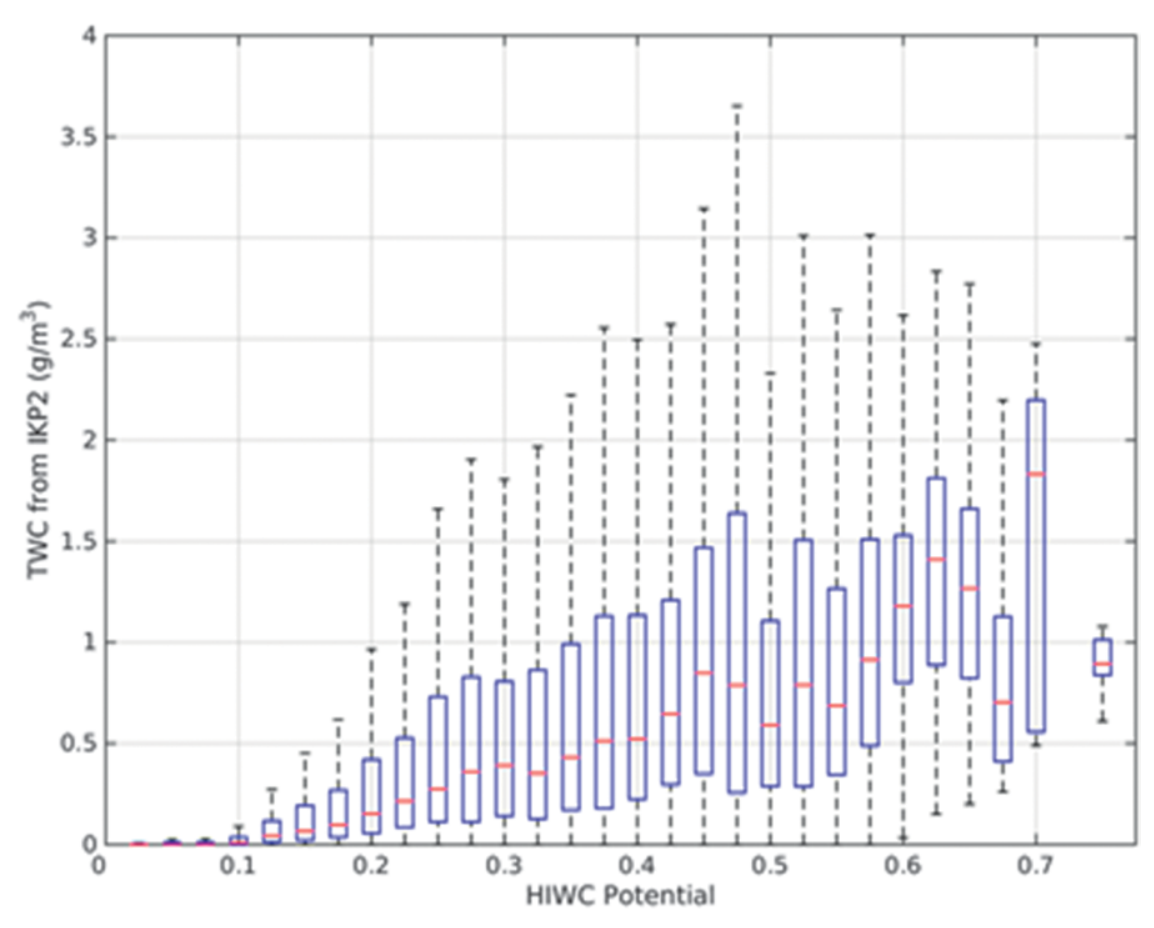

Fig. 7. Boxplot showing relationship between measured TWC and HIWC potential estimated by NCAR's ALPHA, which was objectively trained using airborne in situ data from the IKP2 for three field experiments as described in the text. The median (50th percentile) is indicated in red, the blue box extends from the 25 th to 75 th percentile, and the dashed lines extend to the minimum/maximum nonoutlier values.

threshold value may be only one of the criteria required for ICI events to occur. For example, there is some indication that simply exceeding a particular IWC for a brief period of time may not be as hazardous to engines as a longer duration exposure to moderate and high IWC. In addition, there are differences in sensitivity of specific engines to high-IWC exposure. Obtaining a better understanding of these factors is critical for refining the existing products. Unfortunately, this information is generally not provided by airlines and aircraft manufacturers to researchers, a circumstance that limits further improvement of high-IWC detection and nowcasting techniques.

OPERATIONAL APPLICATIONS. In response to the ICI hazard, researchers have responded with a collection of prototype methods for identifying high-IWC conditions and have verified the resulting products with available research data. The products exhibit reasonable probabilities of detection but often with significant false alarm rates. Ongoing research will address the need for regional tuning of algorithms, vertical variation of high-IWC conditions, and short-term forecasting methods for predicting the ICI hazard. In addition, the integration of geostationary satellite data from multiple satellites (i.e., MSG, the GOES-R series, and Himawari-8) together with global NWP models allows for the provision of operational ICI guidance products with global coverage.

In parallel with this research, the International Civil Aviation Organization (ICAO) has recognized a requirement by the international aviation industry for HIWC guidance products and is working to develop service requirements. Outreach efforts are currently underway to introduce high-IWC detection capabilities to weather forecasters and airline users. Under a joint effort by the Australian Bureau of Meteorology, NCAR, and the FAA, real-time ALPHA products are being provided to industry users on a trial basis. The LaRC PHIWC products are being provided to several NOAA national forecast centers and central weather service units to enable near-real-time identification of hazardous convection. RDT is now produced globally by Météo-France using five geostationary satellites, and the product is available to aviation end users. Feedback from these users will be an important source of information for refining the capability and utility of these products in real-world settings.

RECOMMENDATIONS. Working in the context of a larger international collaboration, the high-IWC nowcasting researchers have demonstrated the value of synergistic effort toward a common goal. As noted by Pablo Perez Illana (HAIC project office, European Commission, Directorate General for Research and Innovation, Aviation), "the interdisciplinary, international and interactive approach is worth highlighting" (P. Perez Illana 2018, personal 
communication). He notes that the HAIC-HIWC collaboration brings together experts from numerous disciplines within the meteorology and aviation communities. It also serves as an example for successful transatlantic and multilateral collaboration, being the largest European Union cofunded aviation research project with North America.

The sustained collaborative effort between international teams devoted to the high-IWC nowcasting challenge has resulted in a set of prototype products for detecting ICI hazards. Continued development and improvement of product performance depends on access by researchers to detailed information on engine performance and meteorological conditions during actual ICI events as well as additional in situ IWC measurements collected in future field experiments. Feedback from users in operational settings is needed to define usage concepts and methods for integrating high-IWC products with other aviation weather products. Future efforts will benefit from additional interaction with the aviation community to define product performance requirements, determine how high-IWC products can best support flight planning and operations, and support the expected growing role of data analytics in aviation.

ACKNOWLEDGMENTS. The authors thank the organizers, collaborators, and sponsors of the HAIC and HIWC projects who enabled the collection of essential datasets for this work and provided support for development of these products. The HAIC authors (De Laat, Defer, Delanoë, Grandin, Moisselin, and Parol) have received funding from the European Union's Seventh Framework Program in research, technological development, and demonstration under Grant Agreement ACP2GA-2012-314314. The research conducted by one of the authors (Haggerty) is in response to requirements and funding by the Federal Aviation Administration (FAA). The views expressed are those of the authors and do not necessarily represent the official policy or position of the FAA. NCAR is sponsored by the National Science Foundation. NASA HIWC research (Bedka) was supported by the Advanced Air Transport Technology Project within the NASA Aeronautics Research Mission Directorate Advanced Air Vehicles Program.

\section{FOR FURTHER READING}

Ackerman, A. S., A. M. Fridlind, A. Grandin, F. Dezitter, M. Weber, J. W. Strapp, and A. V. Korolev, 2015: High ice water content at low radar reflectivity near deep convection-Part 2: Evaluation of microphysical pathways in updraft parcel simulations. Atmos. Chem. Phys., 15, 11 729-11 751, https://doi.org/10.5194 /acp-15-11729-2015.

Adams, E., 2018: The world's biggest jet engine is about to get a blast of ice. Wired, accessed 15 January 2018, www.wired.com/story/testing-boeings-new-engine/. Aviation Safety Network, 2016: FAA orders engine icing fixes for GEnx-powered Boeing 787 Dreamliners. Flight Safety Foundation, accessed 1 December 2017, http://news.aviation-safety.net/2016/04/23 /faa-orders-engine-icing-fixes-for-genx-powered -boeing-787-dreamliners/.

Bedka, K. M., and K. Khlopenkov, 2016: A probabilistic pattern recognition method for detection of overshooting cloud tops using satellite imager data. J. Appl. Meteor. Climatol., 55, 1983-2005, https://doi .org/10.1175/JAMC-D-15-0249.1.

— J. T. Allen, H. J. Punge, M. Kunz, and D. Simanovic, 2018: A long-term overshooting convective cloud top detection database over Australia derived from MTSAT Japanese Advanced Meteorological Imager observations. J. Appl. Meteor. Climatol., 57, 937-951, https://doi.org/10.1175/JAMC-D-17-0056.1.

Bravin, M., J. W. Strapp, and J. Mason, 2015: An investigation into location and convective lifecycle trends in an ice crystal icing engine database. SAE International Tech. Paper 2015-01-2130, 8 pp., https://doi .org/10.4271/2015-01-2130.

Ceccaldi, M., J. Delanoë, R. J. Hogan, N. L. Pounder, A. Protat, and J. Pelon, 2013: From CloudSat-CALIPSO to EarthCare: Evolution of the DARDAR cloud classification and its comparison to airborne radar-lidar observations. J. Geophys. Res. Atmos., 118, 7962-7981, https://doi.org/10.1002/jgrd.50579.

Davison, C. R., J. W. Strapp, L. Lilie, T. P. Ratvasky, and C. Dumont, 2016: Isokinetic TWC evaporator probe: Calculations and systemic error analysis. Eighth Atmospheric and Space Environments Conf., Washington, D.C., American Institute of Aeronautics and Astronautics, 4060, https://doi.org/10.2514 /6.2016-4060.

de Laat, A., and Coauthors, 2017: Analysis of geostationary satellite-derived cloud parameters associated with environments with high ice water content. Atmos. Meas. Tech., 10, 1359-1371, https://doi.org/10.5194 /amt-10-1359-2017.

Delanoë, J., and R. J. Hogan, 2008: A variational scheme for retrieving ice cloud properties from combined radar, lidar, and infrared radiometer. J. Geophys. Res., 113, D07204, https://doi.org/10.1029/2007JD009000. 
Dezitter, F., A. Grandin, J.-L. Brenguier, F. Hervy, H. Schlager, P. Villedieu, and G. Zalamansky, 2013: HAIC-High altitude ice crystals. Fifth Atmospheric and Space Environments Conf., San Diego, CA, American Institute of Aeronautics and Astronautics, 2674, https://doi.org/10.2514/6.2013-2674.

Fang, G., N. M. Kwok, and Q. Ha, 2008: Automatic fuzzy membership function tuning using the particle swarm optimization. Pacific-Asia Workshop on Computational Intelligence and Industrial Application, Wuhan, China, Institute of Electrical and Electronics Engineers, 324-328.

Grandin, A., J.-M. Merle, M. Weber, J. Strapp, A. Protat, and P. King, 2014: Airbus flight tests in high total water content regions. Sixth Atmospheric and Space Environments Conf., Atlanta, GA, American Institute of Aeronautics and Astronautics, 2753, https://doi .org/10.2514/6.2014-2753.

Grzych, M., and J. Mason, 2010: Weather conditions associated with jet engine power loss and damage due to ingestion of ice particles: What we've learned through 2009. 14th Conf. on Aviation, Range, and Aerospace Meteorology, Atlanta, GA, Amer. Meteor. Soc., 6.8. https://ams.confex.com/ams/pdfpapers/165923.pdf.

—, T. Tritz, J. Mason, M. Bravin, and A. Sharpsten, 2015: Studies of cloud characteristics related to jet engine ice crystal icing utilizing infrared satellite imagery. SAE International Tech. Paper 2015-01-2086, 16 pp., https://doi.org/10.4271/2015-01-2086.

Haggerty, J., F. McDonough, J. Black, G. Cunning, G. McCabe, M. Politovich, and C. Wolff, 2012: A system for nowcasting atmospheric conditions associated with jet engine power loss and damage due to ingestion of ice particles. Fourth Atmosphere and Space Environment Conf., New Orleans, LA, American Institute of Aeronautics and Astronautics, 3234, https://doi .org/10.2514/6.2012-3234.

Lawson, R. P., L. J. Angus, and A. J. Heymsfield, 1998: Cloud particle measurements in thunderstorm anvils and possible weather threat to aviation. J. Aircr., 35, 113-121, https://doi.org/10.2514/2.2268.

Leroy, D., and Coauthors, 2017: Ice crystal sizes in high ice water content clouds. Part II: Statistics of mass diameter percentiles in tropical convection observed during the HAIC/HIWC project. J. Atmos. Oceanic Technol., 34, 117-136, https://doi.org/10.1175/JTECH-D-15-0246.1.

Mason, J. G., J. W. Strapp, and P. Chow, 2006: The ice particle threat to engines in flight. 44th Aerospace Sciences Meeting, Reno, NV, American Institute of Aeronautics and Astronautics, 206, https://doi .org/10.2514/6.2006-206.

Protat, A., J. Delanoë, D. Bouniol, A. J. Heymsfield, A. Bansemer, and P. Brown, 2007: Evaluation of ice water content retrievals from cloud radar reflectivity and temperature using a large airborne in-situ microphysical database. J. Appl. Meteor. Climatol., 46, 557-572, https://doi.org/10.1175/JAM2488.1.

Rugg, A., J. Haggerty, G. McCabe, R. Palikondra, and R. Potts, 2017: High ice water content conditions around Darwin: Frequency of occurrence and duration as estimated by a nowcasting model. Ninth Atmosphere and Space Environment Conf., Denver, CO, American Institute of Aeronautics and Astronautics, 4472, https://doi.org/10.2514/6.2017-4472.

Stanford, M. W., A. Varble, E. Zipser, J. W. Strapp, D. Leroy, A. Schwarzenboeck, R. Potts, and A. Protat, 2017: A ubiquitous ice size bias in simulations of tropical deep convection. Atmos. Chem. Phys., 17, 9599-9621, https://doi.org/10.5194/acp-17-9599-2017.

Strapp, J. W., and Coauthors, 2016: The High Ice Water Content (HIWC) study of deep convective clouds: Report on science and technical plan. Federal Aviation Administration Rep. DOT/FAA/TC-14/31, 105 pp., www.tc.faa.gov/its/worldpac/techrpt/tc14-31.pdf. Yost, C. R., and Coauthors, 2018: A prototype method for diagnosing high ice water content probability using satellite imager data. Atmos. Meas. Tech., 11, 1615-1637, https://doi.org/10.5194/amt-11-1615-2018. 